\title{
FSEを用いたDynamic MRIの臨床応用
}

Clinical Application of Dynamic MRI using FSE

札幌医科大学医学部附属病院 放射線部

$\begin{array}{ccc}\text { O白勢竜二 } & \text { 板東道夫 坂田元道 小田原好宏 鎌形政樹 原田 邦明 } \\ \text { Ryuji Shirase } & \text { Michio Bandoh } & \text { Motomichi Sakata Yoshihiro Odawara Masaki Kamagata Kuniaki Harada }\end{array}$

\section{(目 的)}

腫瘍の血流状態の把握や下垂体腫瘍のような微細な病変の描出にはDynamic MRIが有用である。しかしGRE法を用 いたものはsusceptibility artifactにより画質が劣化する可能性がある。今回我々は頭部、特に下垂体や眼窩部におけ る腫瘍のDynamic MRIにFSE法を用い、撮像条件の最適化と臨床応用を試み、良好な結果を得たので報告する。

(装 置)

GE社製 SIGNA1.5T ver.4.8 headcoil及び3inch surfacecoil

(撮像条件及び方法)

シーケンス:Fast Spin Echo

TR:120msec、TE:minimum

ET:2

matrix:256x128

NEX:2NEX

FOV:16〜 $12 \mathrm{~cm}$

スライス厚:3〜 $4 \mathrm{~mm}$

(ETの比較)

図2はETを $2,4,8,16$ 変化させて比較したものである。ETを2 あるいは4に設定すると、コントラストの良好な画像が得られる。

(各シークンスの比較)

SE DynamicはS/Nが悪く、SPGR Dynamicはsusceptibility artifactによって下垂体の形が歪んで描出されている。 それに対し、FSE Dynamicは良好に描出されている（図3）。 (結 果)

2locationを設定することにより信号低下が防止できる。 ETを2or4に設定することにより、コントラストの良好な画像が得られる。

(臨床例 1-pituitary microadenoma-困4)

T1,T2,enhanceのいずれを見ても腫瘍の存在や大きさが はっきりしないがDynamic MRIだと明瞭に描出されている。

\section{(臨体例 2-orbital tumor-四5)}

本法の利点である2ヶ所同時に撮像可能なことと、脂肪抑制が 併用できることを応用した例である。眼窝内の脂肪が抑制され、 腫嚎の前部では鼻側から後部では中央部から造影されている。

(まटめ)

FSEを用いたDynamic MRIは2location、2ETを選択する ことにより、良好な画像が得られることが確認され、 susceptibility artifactが少ない、2ヶ所同時に撮像ができる、 脂肪抑制が併用できるといった利点を持つが、flow artifact、 S/Nの問題を考慮して使用する必要がある。また本法はFSEと $2 \mathrm{ET}$ 使用しているので既存の装置で簡便に臨床応用が可能となる。

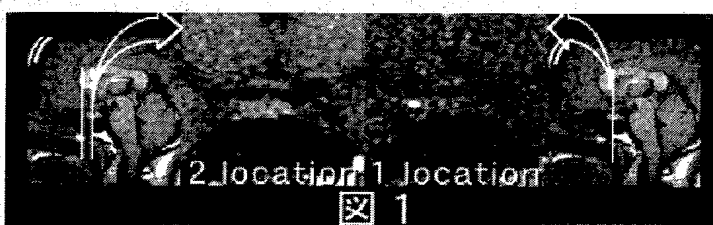

图 1

Dynamic MRIを行うにはScan Timeの短縮が必須条件となるので、まずTRを 最小の60msecと設定する。この場合、1acquisitionで1slice撮像することにな る。この条件ではS/Nが低下する。そこで、TRを120～140msecに設定する。 この場合、1acquisitionで2slice撮像することになり、断面を1のみ設定すると、 同一TR内で 1 番目と2番目のスライスを同時に励起することになり、信号が低 下する。そこで断面を2つ設定することで信号低下の少ない画像が得ることが
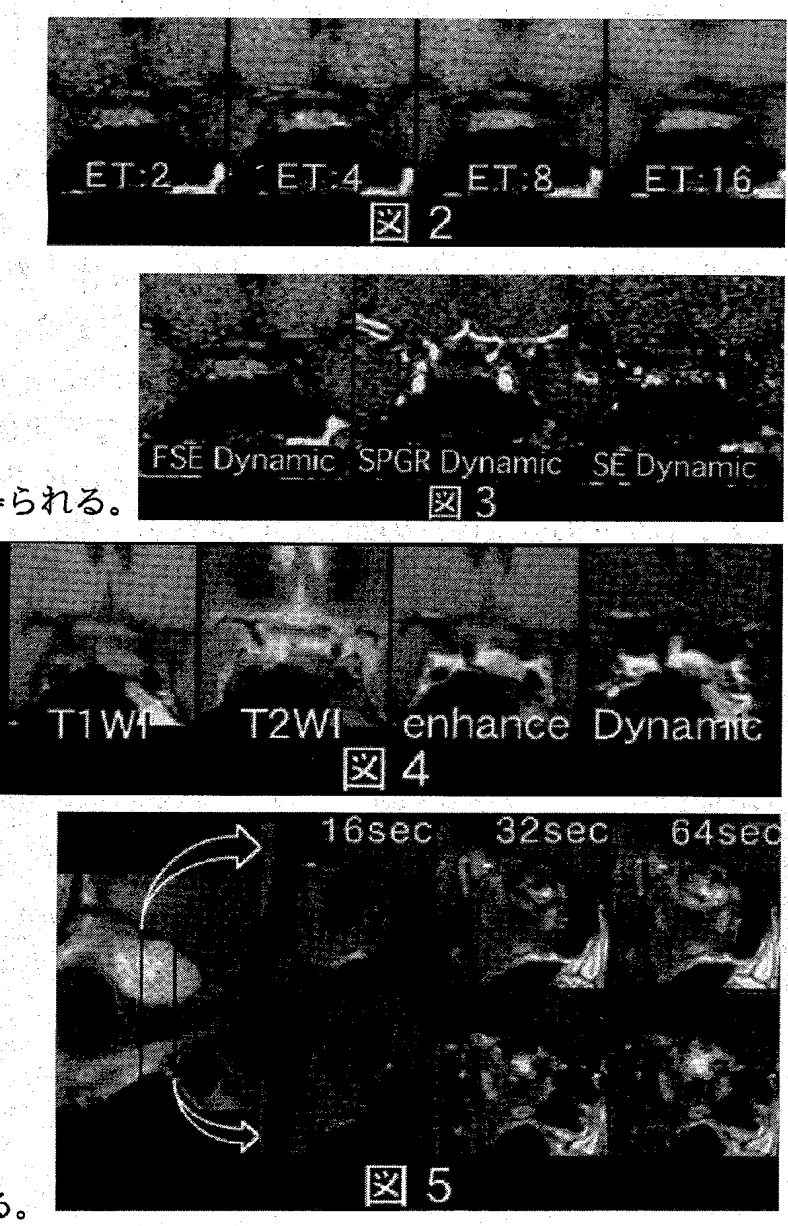